KEYWORDS

Economic growth

Economic conditions

Macroeconomy

Raw materials

Prices

Capital movements

International finance

Foreign exchange rates

Economic policy

Monetary policy

Fiscal policy

Economic statistics

Latin America

José Antonio Ocampo

Professor at Columbia University,

Former Executive Secretary of ECLAC

¡jao2128@columbia.edu
CEPAL REVIEW 93 D DEEMBER 2007

\section{The macroeconomics of the Latin American economic boom}

\author{
José Antonio Ocampo
}

$\mathrm{T}$

his paper argues that the recent boom in the Latin American economies can be explained by the conjunction of two external factors not found together since the 1970s: strong commodity prices (more so for hydrocarbons and mining products than for agricultural commodities) and exceptional external financing conditions. Concerning the latter, the key development was the massive influx of capital during two periods of "exuberance" in international financial markets (between mid-2004 and April 2006, and between mid-2006 and mid-2007), particularly the second. It also argues for the importance of spreading and consolidating Latin America's two great (and complementary) macroeconomic policy innovations of recent years: countercyclical fiscal management (still confined to just a few countries) and active intervention in currency markets. Such intervention needs to be based on a growing recognition that the real exchange rate ought to be an explicit goal of macroeconomic policy. 


\section{I}

\section{Introduction}

In 2007, Latin America will have had four consecutive years of rapid growth (ECLAC, 2007a). There has not been a period of such strong economic expansion in the region since the long post-war boom that culminated in the debt crisis (or a few years earlier in some countries). This situation has come, furthermore, after almost a quarter of a century of unsatisfactory performance marked by the "lost decade" of the 1980s, the "lost half-decade" of 1998-2002 and a period of weak performance between the two. What is more, the current situation is characterized by a combination of rapid growth and a large current account surplus that is exceptional in Latin America's economic history, as well as by improved labour market, poverty and income distribution. The countries have also adopted a more explicit policy of intervening in currency markets and increasing their external assets, while the tendency to follow procyclical macroeconomic policies has been corrected to some extent. So far, however, progress with the latter has been largely confined to just a few countries.

This paper analyses the current macroeconomic situation and seeks to identify its particular characteristics. After examining the main macroeconomic results and their relationship with world economic conditions (section II), it looks more closely at the effects of movements in international financial markets (section III), analyses macroeconomic policy developments in the region's seven largest economies (section IV) and ends with some brief conclusions (section $\mathrm{V}$ ).

\section{II}

\section{The current situation and the international context}

In the past few years, Latin America has at last returned to the economic growth rates of the 1970s. Given that the two largest Latin American economies (Brazil and Mexico) have performed less well now than they did then, the indicators look even better when simple averages of GDP growth in the region's countries are compared. If that is done, the situation now is an improvement on the 1970s. Furthermore, since the rate of population increase has fallen sharply, the results look even more impressive when calculated in terms of per capita output growth.

The explanation for this is basically to be sought in the exceptional conditions prevailing in the international

$\square$ A version of this paper was presented at the fourth economic forum of the Getulio Vargas Foundation on 17 September 2007. The author is grateful to Rudy Loo-Kung, Julio Marichal, Mariangela Parra, Helvia Velloso and Jürgen Weller for providing the necessary statistical information. Discussions with Guillermo Calvo and Osvaldo Kacef helped to clarify some of the ideas dealt with here. economy over the last few years. ${ }^{1}$ Although, as we shall see later, some aspects of macroeconomic management have been more effective than in the past, this is not necessarily something that contributes to short-term growth. Indeed, it is possible that the countercyclical macroeconomic policies the Latin American countries have begun adopting, albeit very unevenly, might actually be sacrificing current demand growth to an improved ability to deal with adverse economic conditions in future. Nor can the improvement in performance be attributed to economic reforms, whose effects on the production structure and economic growth have been much debated and may actually have been more negative than positive. ${ }^{2}$ From a Schumpeterian perspective of "creative destruction", however, it might perhaps

\footnotetext{
${ }^{1}$ See the recent essay by Izquierdo, Romero and Talvi (2007).

${ }^{2}$ For an ambivalent assessment from a perspective that is generally favourable to the reforms, see Kuczynski and Williamson (2003). A more critical evaluation can be found in Ocampo (2004).
} 
be said that the reform-led phase of destruction in the countries' production capacity is now over, and that what should prevail from now on are rather the factors favouring the creation of new export capabilities. The absence or weakness of productive development policies, however, is still one of the main shortcomings of economic policy in the region.

The current boom is basically due, then, to the conjunction of two favourable factors of external origin not seen together since the 1970s: strong commodity prices and exceptional external financing conditions. The economic history of Latin America shows that this combination leads infallibly to rapid economic growth. In the current circumstances, however, the transmission mechanisms for external financing have been somewhat different, mainly because governments have been far more circumspect in their use of such financing.

To these two favourable factors must be added a third: large remittances by Latin American migrants to their home countries. This factor has had a large effect on the economies that are closest geographically to the United States and, interestingly enough, has been particularly important in most of the small economies whose terms of trade have deteriorated in recent years because of high oil prices. Meanwhile, the boom in international trade has boosted growth in the manufactured goods and services exports on which the region (and especially the economies of Mexico, Central America and the Caribbean) increasingly depends.

It should be added that the external situation is also exceptional in another way: this is the first period in global economic history when per capita GDP has grown much faster in the developing countries than in the industrialized world, i.e., the first reversal of the tendency in global economic history for development levels in the two sets of countries to diverge (United Nations, 2006). However, it is still too soon to speak of true long-term convergence in these levels, except in the case of some Asian economies. Moreover, the current boom has encompassed every region of the developing world and, among them, Latin America has been in fact the weakest performer (United Nations, 2007).

The factors giving rise to this exceptional performance are well known. High raw material prices are mainly due to the heavy dependence of the Chinese economy on commodity imports. Exceptional financing conditions, in turn, reflect a wide array of factors: (i) the tolerance of the monetary authorities in the world's leading economies for low interest rates, owing to low inflation levels; (ii) major financial innovations that, combined with the search for higher returns, multiplied the demand for and liquidity of riskier financial instruments; (iii) the consequent large reduction in the risk premiums of such securities, and (iv) the large build-up of developing countries' international reserves, owing to the saving of exceptional foreign exchange surpluses and the demand for "self-insurance" that arose after the Asian crisis, when it became clear that there was no international mechanism for dealing with crises caused by sudden stops in external financing. Some of these conditions, particularly the second, are changing. Rising remittances, meanwhile, reflect growing movements of labour (both regular and irregular) from Latin America to the industrialized countries, partly because of very limited job creation in the region during the "lost half-decade".

Figure 1 shows the long-term rise in commodity prices, taking the 1945-1980 period as the base. As it illustrates, this has been much less exceptional than is usually thought. Indeed, the drop in real prices for nonoil commodities in the 1980s and 1990s has yet to be reversed. In addition, the process has been very uneven, benefiting mining products more than agricultural ones. In real terms (deflated by a manufacturing price index), metal prices in 2006 stood $76 \%$ above the 1945-1980 average, an extraordinary level surpassed only in a few years in the early twentieth century. Conversely, prices for tropical and temperate zone agricultural products in 2006 were still $41 \%$ and $29 \%$, respectively, below their 1945-1980 levels; some of these prices have risen in 2007, however, because of the biofuels boom. Price rises for oil and gas have come on top of those for mining products, although the oil price only very recently rose back to its 1970s level in real terms. Thus, the recent commodity price boom involves hydrocarbons and mining products more than agricultural commodities. It is still too soon to speak of long-term improvements in real prices reversing the downward trend in non-oil commodity prices seen over the twentieth century (Ocampo and Parra, 2003).

Among the factors helping Latin America's current account balance over recent years, the dominant one has been the improvement in its terms of trade, amounting to the equivalent of $3.4 \%$ of gross domestic product (GDP) for the region as a whole between 2003 and 2006 (table 1). Some of these gains were automatically taken out in the form of profit remittances by foreign firms active in mining sectors. However, while this effect has been large in some countries, for the region as a whole the factor income balance trend has improved marginally as net production factor payments and the cost of foreign debt have fallen relative to GDP. Meanwhile, migrants' 
FIGURE 1

Real commodity price index

$(1945-1980=100)$

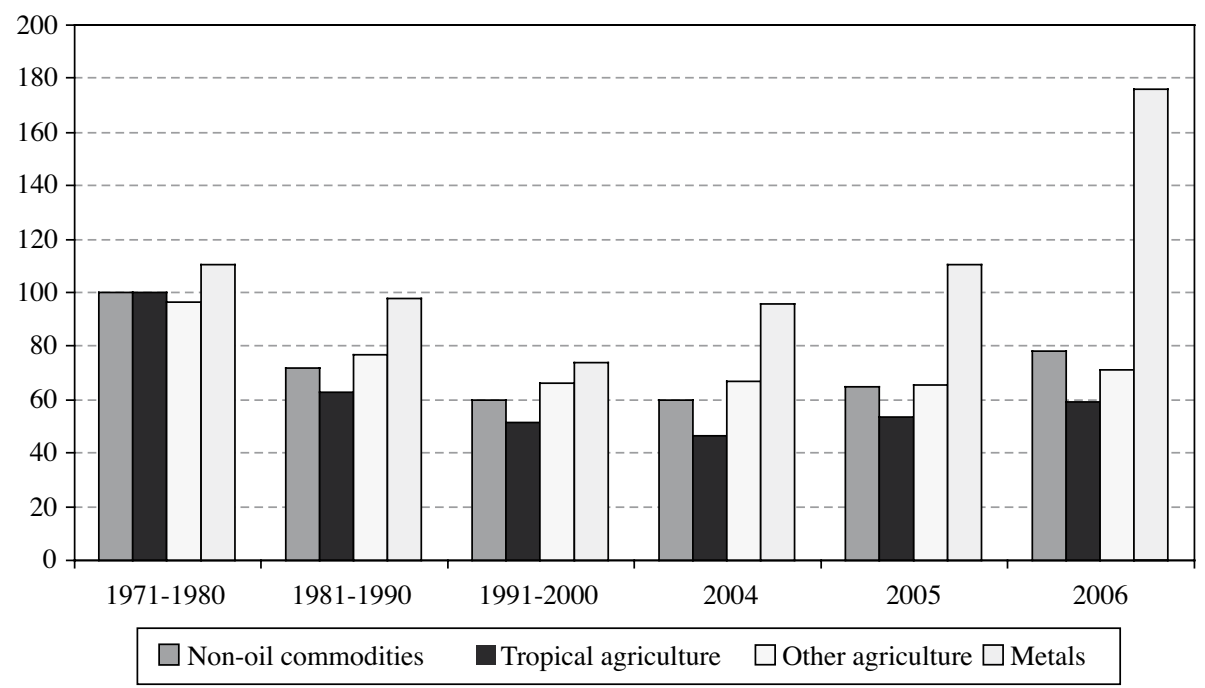

Source: Original data from Ocampo and Parra (2003), updated with individual product information from the United Nations Conference on Trade and Development (UNCTAD).

remittances, which improved the balance of payments by $0.9 \%$ of GDP between 2000 and 2003, have not made a major additional contribution in recent years, although they are still a major source of income for some of the region's smaller economies.

The fact is that, in net terms, the greatest contributor to the balance of payments after the improvement in the terms of trade has been increased net financial flows, a reflection once again of their markedly procyclical character. This tendency also contrasts with that of net foreign direct investment, reflecting the twofold effect of lower investment in Latin America and the expansion of Latin American firms abroad.

The relative importance of financial flows and improved terms of trade is better observed if the Bolivarian Republic of Venezuela is excluded from the calculations, as the country has experienced the greatest terms-of-trade gains while its capital account is dominated by official capital flows. As table 1 shows, when the Venezuelan economy is excluded from the calculations, the improvement in the terms of trade between 2003 and 2006 falls to 2.5 points of GDP while the increase in financial flows rises to 1.7 points. Furthermore, the importance of external financing was particularly marked during the phases of "exuberance" in international financial markets, as will be seen in section III of this paper.
The most striking new feature of the current situation is the region's ability to grow quickly while at the same time generating a current account surplus, and thus a net transfer of resources abroad. This combination, characteristic of the dynamic economies of East Asia, is unprecedented in the region's history. As figure 2 shows, the closest parallel is with the situation of the 1950s and 1960s, when Latin America combined growth with small current account surpluses (or small deficits, if the Bolivarian Republic of Venezuela is excluded). In the 1970 s, the region kept on growing rapidly but became dependent on net transfers of resources from abroad, and the same happened when economic growth resumed, but more slowly, in 1990-1997. As is well known, the great volatility of financial flows meant that depending on external resources for growth ultimately proved counterproductive on both occasions.

Does this mean we are on the verge of a shift towards long-term economic growth with current account surpluses, as in many of the most successful economies of East Asia? The answer, sadly, is no. The most important achievement in the current situation has been the improvement in the region's external borrowing position (figure 3, panel A). Combined with the debt reduction processes of recent years, this means that the pressure of large external debts will be felt less in future or, to be accurate, will be felt in a smaller group of countries. 
TABLE 1

Latin America and the Caribbean: Factors underlying the improvement in the balance of payments

(Percentages of gross domestic product in current dollars)

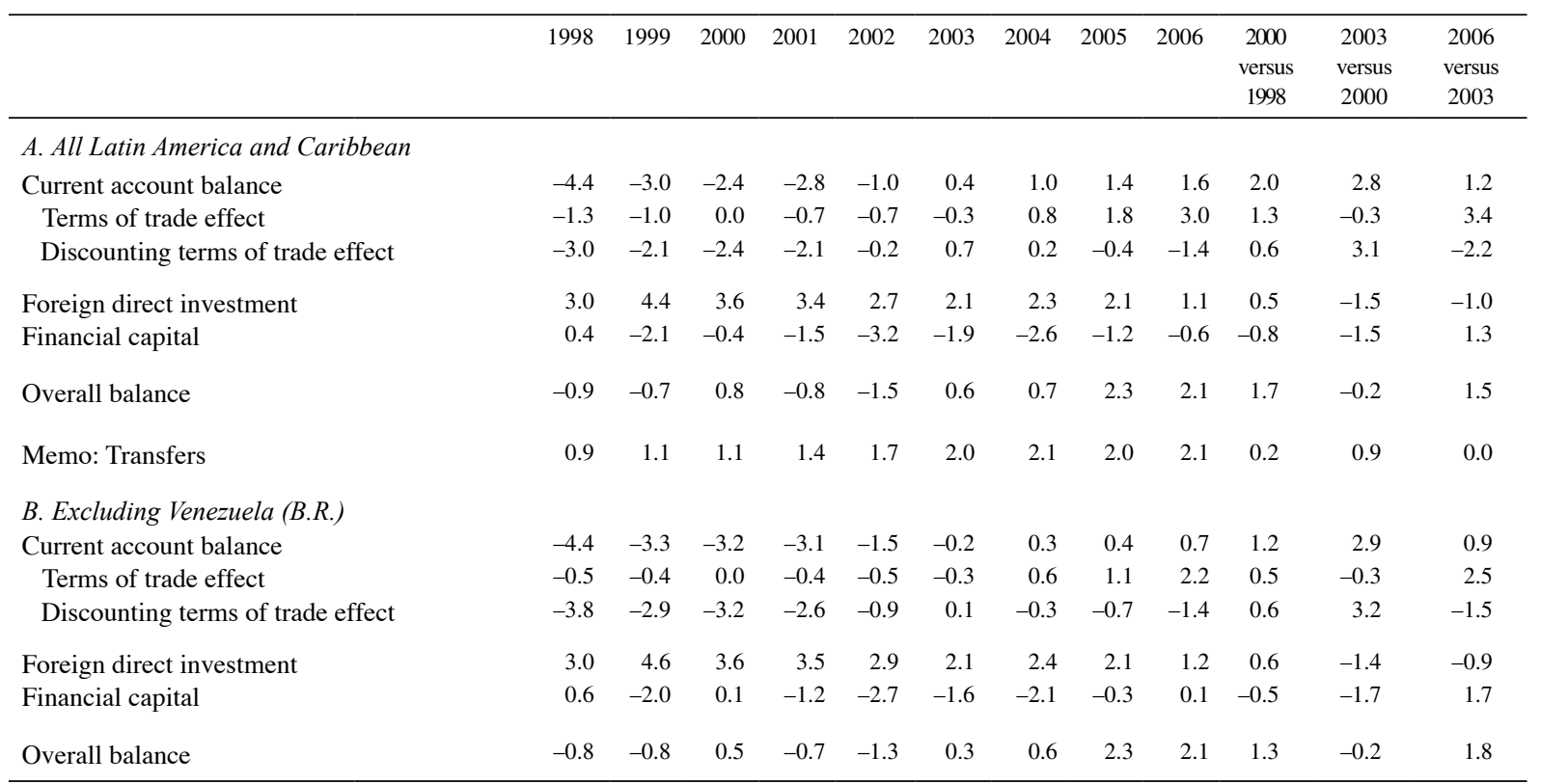

Source: Author's calculations based on ECLAC statistics.

FIGURE 2

Latin America and the Caribbean: Relationship between the goods and services balance and economic growth

(Percentages)

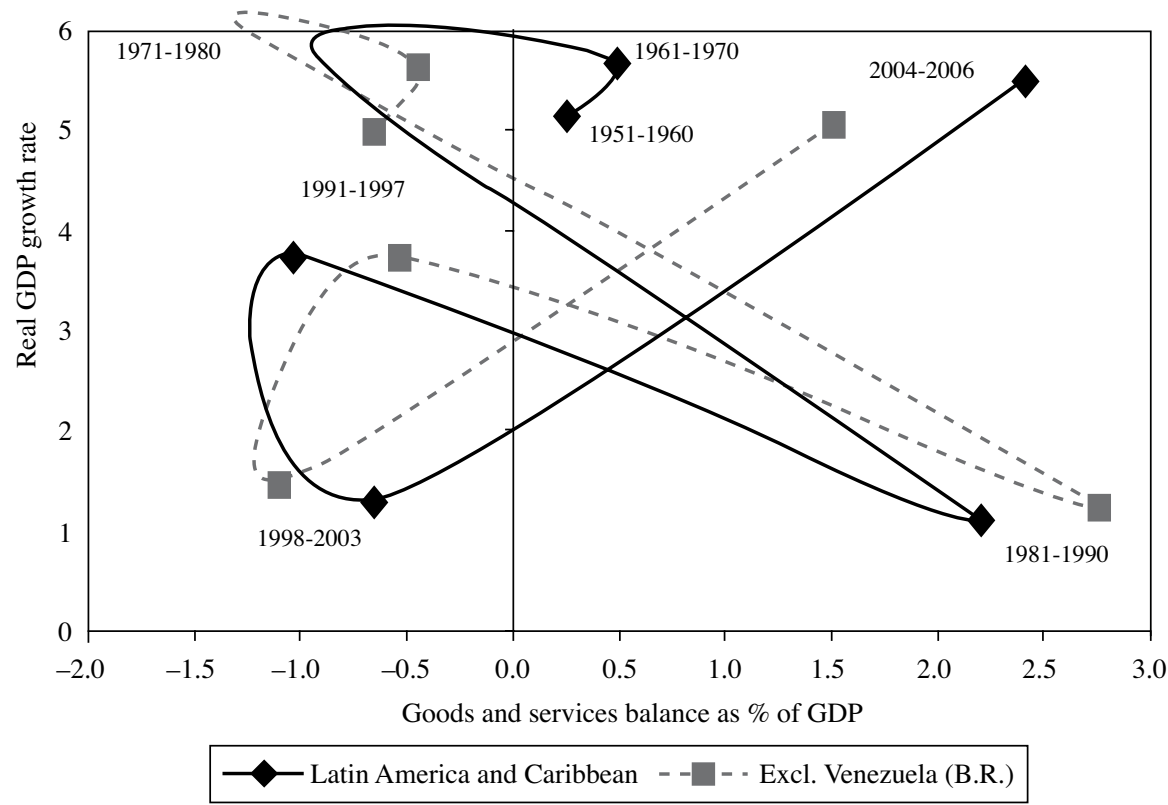

Source: Author's calculations based on ECLAC statistics. 
Conversely, the current account surplus has two important characteristics that undermine its positive effect. First, it is largely confined to just seven countries, five of them oil or mineral producers (Bolivia, Chile, Ecuador, Peru and the Bolivarian Republic of Venezuela) and two with more diversified export structures (Argentina and Brazil). Of the latter, Brazil's current account could move into deficit in the near future. Second, when adjusted for the improvement in the terms of trade, the current account has been in deficit since 2005 and is deteriorating rapidly, which means that deficits in 2007 will be very similar to those of 2000-2001 (figure 3, panel B). The conjunction of these two factors indicates that the current account surplus is heavily dependent on the boom in international hydrocarbon and mineral prices. Therefore, the improvement in the current account should be viewed with the caution recommended by Calvo and Talvi (2007) rather than with the optimism that is common among other observers. Indeed, the calculations of

Latin America: External debt and the current account

A. External debt as \% of GDP

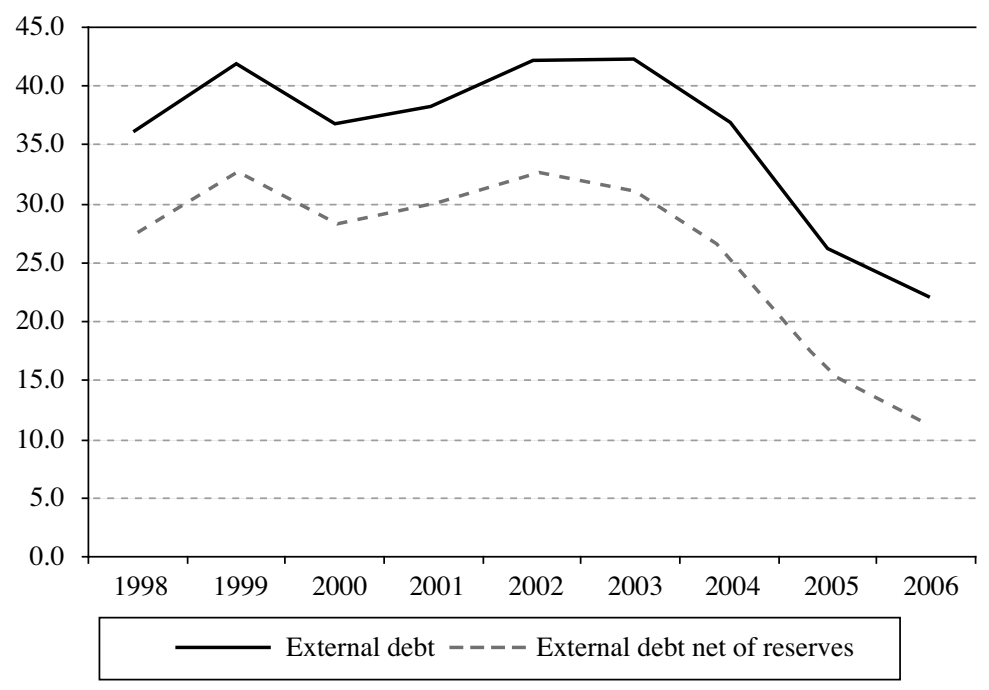

B. Current account, adjusted and unadjusted for the terms of trade, as \% of GDP

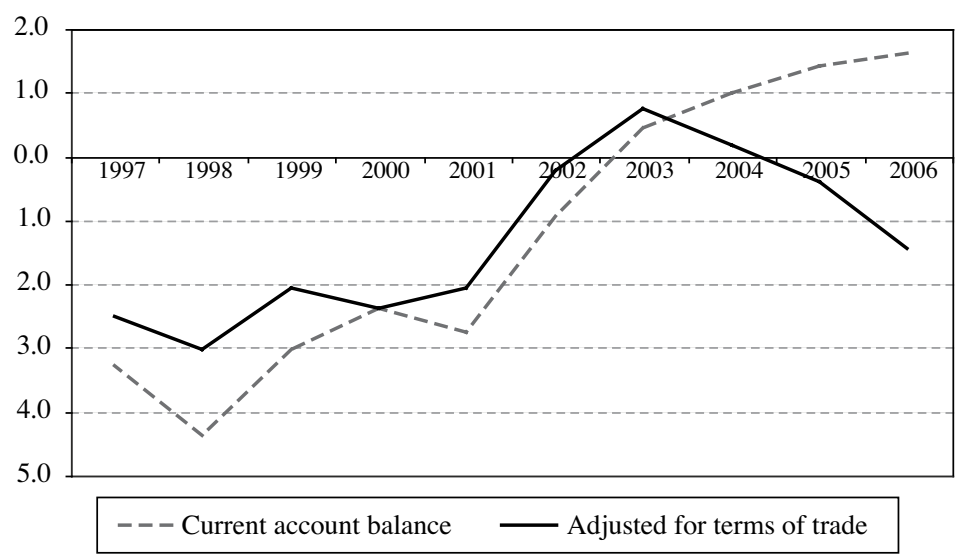

Source: Author's calculations based on data from ECLAC (2007a). 
those authors are much more unfavourable than those shown in figure 3 , panel B. ${ }^{3}$

The above analysis indicates, then, that the situation of rapid growth with large current account surpluses is unlikely to continue in future and that the region's balance of payments depends heavily on exceptional international prices for hydrocarbons and minerals. Although it is not impossible that this situation may persist if the Chinese economy continues its rapid expansion, the lesson from the region's economic history is that it is perilous to assume that high commodity prices will be permanent. Again, the severe turmoil in international financial markets in the third quarter of 2007 reminds us that this other source of the current boom - exceptional external financing conditions - may also weaken as time goes on. This is compounded, of course, by the uncertainty surrounding economic growth around the world, and especially in the United States, as a result of these events.

\section{III}

\section{The effects of international}

\section{financial movement}

Although commodity prices have recently played a decisive role in the macroeconomic dynamics of Latin America, the international financial markets have also had a major influence. The nature of financial flows has changed and so, consequently, have the transmission mechanisms. Indeed, every boom has its own specific features: in the 1970s, inflows derived essentially from lending by groups of banks ("syndicated loans"), but in the 1990s they came mainly from international bond issues.

The nature of recent financial flows can be better appreciated from the external balance sheets shown in table 2. This table, which covers the seven largest Latin American economies, reveals two striking changes. The first is the increase in assets, particularly international reserves but also direct and portfolio investments abroad, which in all cases grew by even more than these seven economies' GDP in current dollars (which itself rose by $65 \%$ between 2003 and 2006). The second is the large shift in the composition of liabilities, essentially driven by the reduction in borrowing and the rise of securities portfolio liabilities. The latter include investments in both the share and bond markets of the region's countries by international investment funds. The counterpart to this shift in assets and liabilities, therefore, has been the boom in both domestic bond markets (table 2) and stock markets.

\footnotetext{
${ }^{3}$ See also ECLAC (2006, pp. 20-21).
}

There are two further features of this balance sheet that are worth highlighting. First, net external liabilities have fallen sharply: by some 10 percentage points of GDP between 2003 and 2006, mostly in the net financial position. This is true, furthermore, for six of the seven largest Latin American economies (the exception is Mexico). Three of them (Argentina, Chile and the Bolivarian Republic of Venezuela) now have a positive net financial position. Again, the reserves build-up looks extremely sound when compared with debt liabilities, but much less so if the comparison is with all portfolio liabilities. One way of looking at it, and this will become much clearer later, is that the build-up of reserves has been matched by a rise in portfolio liabilities. Indeed, reserves in the region's two largest countries only cover a fairly small proportion of portfolio liabilities, while in three countries (especially Mexico, but also Chile and Peru, albeit from a much sounder position), reserves have increased by less than these liabilities.

Figure 4, panel A, shows how exceptional the recent international financial situation has been. Emerging market risk spreads began to narrow dramatically in the last quarter of 2002; since the second half of 2004 they have been systematically lower than they were the year before the Asian crisis, and since mid-2005 they have been lower than those of high-risk bonds in the United States market. Latin America was something of a latecomer to this process, but has improved by more than the average since 2004. Thus, the second half of 2004 appears to mark the beginning of the "exuberance" in international financial markets (to use the term coined by the former 
Latin America (seven largest economies):a External balance sheet

(Percentages of gross domestic product at current prices)

\begin{tabular}{|c|c|c|c|c|c|c|}
\hline & 2001 & 2002 & 2003 & 2004 & 2005 & 2006 \\
\hline \multicolumn{7}{|l|}{ Assets } \\
\hline Totalb & 27.6 & 31.1 & 33.4 & 33.1 & 32.8 & 34.3 \\
\hline Outward direct investment & 6.0 & 7.3 & 7.3 & 7.5 & 7.3 & 8.0 \\
\hline Portfolio holdings & 2.2 & 2.5 & 3.3 & 3.4 & 3.6 & 4.2 \\
\hline Derivatives & 0.0 & 0.0 & 0.0 & 0.1 & 0.0 & 0.0 \\
\hline Other investments & 12.6 & 13.9 & 14.0 & 13.2 & 11.9 & 11.5 \\
\hline International reserves ${ }^{\mathrm{b}}$ & 6.8 & 7.5 & 8.7 & 8.9 & 9.9 & 10.6 \\
\hline \multicolumn{7}{|l|}{ Liabilities } \\
\hline Total $^{\mathrm{a}}$ & 64.9 & 68.5 & 73.6 & 69.6 & 64.1 & 63.8 \\
\hline Foreign direct investment & 25.5 & 26.7 & 29.9 & 29.4 & 27.9 & 27.1 \\
\hline Portfolio holdings & 20.6 & 21.0 & 24.2 & 24.0 & 23.7 & 25.2 \\
\hline Stocks & 5.7 & 5.1 & 7.5 & 8.8 & 10.9 & 13.7 \\
\hline Debt & 14.8 & 15.9 & 16.6 & 15.2 & 12.8 & 11.5 \\
\hline Derivatives & 0.0 & 0.0 & 0.0 & 0.1 & 0.1 & 0.2 \\
\hline Other investments ${ }^{b}$ & 18.8 & 20.7 & 19.5 & 16.1 & 12.4 & 11.3 \\
\hline Assets - liabilities & -37.3 & -37.4 & -40.2 & -36.6 & -31.4 & -29.6 \\
\hline Direct investment & -19.5 & -19.4 & -22.6 & -21.9 & -20.6 & -19.1 \\
\hline Financial & -17.8 & -17.9 & -17.6 & -14.7 & -10.8 & -10.5 \\
\hline Reserves as $\%$ of debt & 20.3 & 20.4 & 24.0 & 28.3 & 39.1 & 46.5 \\
\hline Reserves as $\%$ of portfolio liabilities & 33.1 & 35.5 & 35.9 & 37.0 & 41.6 & 42.1 \\
\hline Domestic bond market as $\%$ of GDP & 33.6 & 32.6 & 40.3 & 40.6 & 46.0 & 51.8 \\
\hline \multicolumn{7}{|l|}{ Financial assets - liabilities } \\
\hline Argentina & -0.3 & 19.8 & 20.1 & 22.0 & 29.5 & 26.2 \\
\hline Brazil & -34.9 & -36.4 & -35.2 & -31.0 & -24.1 & -24.3 \\
\hline Chile & -3.2 & -1.5 & 3.9 & 13.5 & 17.2 & 27.7 \\
\hline Colombia & -15.6 & -15.6 & -16.8 & -11.8 & -6.1 & -3.7 \\
\hline Mexico & -19.3 & -18.3 & -20.4 & -20.4 & -21.3 & -23.8 \\
\hline Peru & -29.4 & -27.7 & -26.4 & -21.3 & -14.4 & -7.5 \\
\hline Venezuela (B.R.) & 23.9 & 35.9 & 48.7 & 44.6 & 49.5 & 51.6 \\
\hline \multicolumn{7}{|l|}{ Reserves as $\%$ of portfolio liabilities } \\
\hline Argentina & 2.2 & -14.2 & 1.7 & 19.6 & 67.6 & 72.8 \\
\hline Brazil & 18.1 & 13.1 & 13.6 & 15.7 & 23.1 & 28.6 \\
\hline Chile & 142.4 & 145.8 & 108.3 & 98.9 & 93.3 & 98.3 \\
\hline Colombia & 78.8 & 88.1 & 84.2 & 91.8 & 102.7 & 96.8 \\
\hline Mexico & 30.8 & 41.6 & 42.7 & 39.0 & 35.8 & 30.0 \\
\hline Peru & 131.1 & 125.4 & 105.2 & 114.4 & 91.7 & 98.2 \\
\hline Venezuela (B.R.) & 113.5 & 93.8 & 111.4 & 109.4 & 123.9 & 161.7 \\
\hline
\end{tabular}

Source: Author's estimates based on IMF International Financial Statistics, GDP in current dollars as per ECLAC data. Bank for International Settlements for domestic bond market data.

a Argentina, Brazil, Chile, Colombia, Mexico, Peru and the Bolivarian Republic of Venezuela.

${ }^{b}$ The value of liabilities with the International Monetary Fund (IMF) is deducted from these accounts.etario Internacional (FMI).

President of the United States Federal Reserve, Alan Greenspan) in relation to developing countries. As table 3 shows, if that period is taken as the starting point for the recent financial boom, the risk spreads of the seven largest economies in the region diminished appreciably in most cases and only moderately in the two countries that were already considered low-risk before the boom (Chile and Mexico). 
The fall in spreads has considerably outstripped the rise in long-term reference interest rates: those of United States Treasury bonds. In fact, long-term interest rates on these bonds have increased only very moderately since the Federal Reserve began raising its rates in September 2004. Thus, the cost of long-term external financing has fallen by almost as much as Latin American risk spreads. On average, meanwhile, the drop in spreads has roughly matched the rise in the shortestterm United States interest rates, so that in this case the net effect has been more varied: while the drop in risk spreads has tended to predominate in Brazil, Colombia

FIGURE 4

\section{Latin America: Risk spreads and stock markets}

A. Emerging-market risk spreads and United States high-risk bonds

(Basis points)

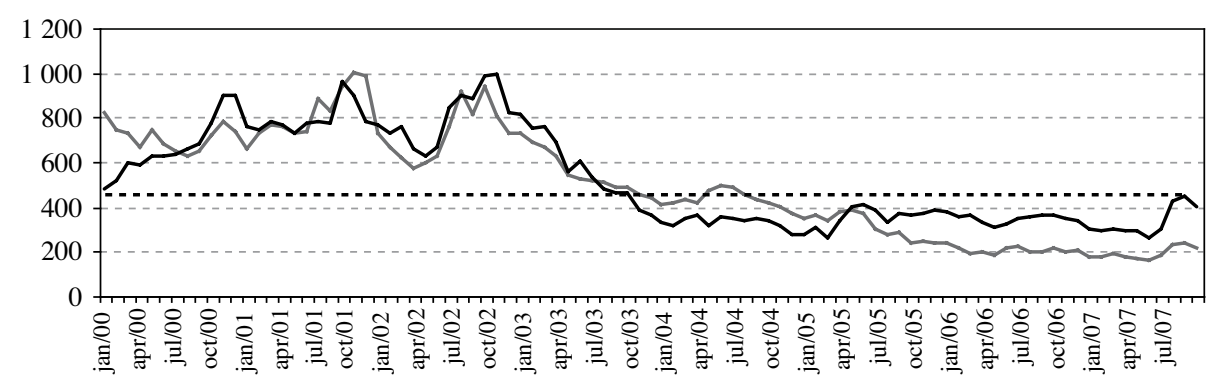

— EMBI — High-risk bonds - -.--- EMBI average for 12 months before Asian crisis

B. Dollar index of Latin American stock markets

(July 2003-June 2004=100)

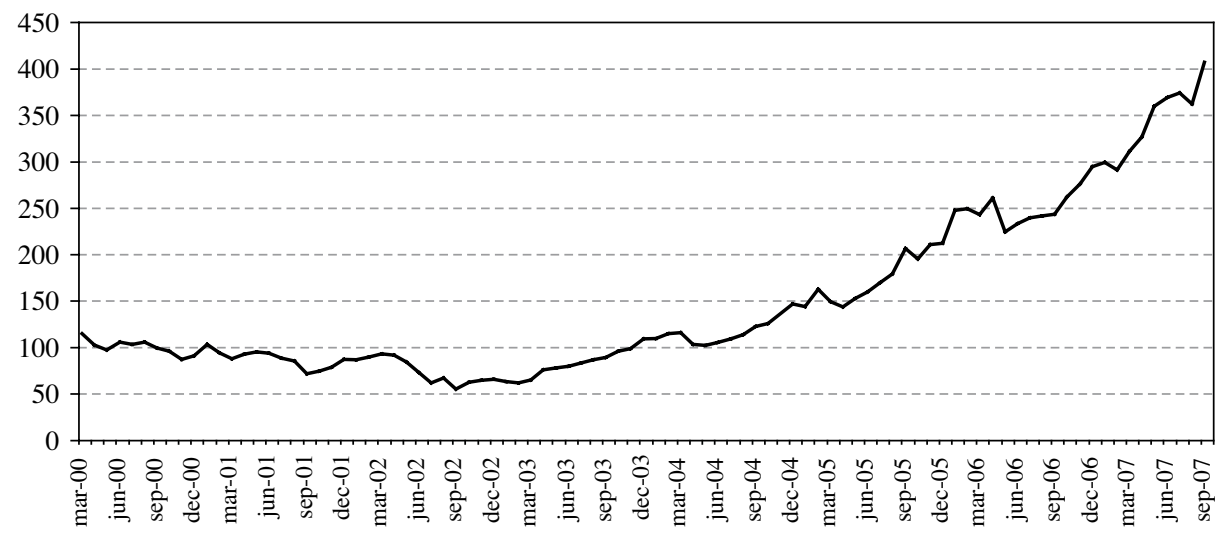

Stock market index

Source: JP Morgan Chase for spreads and risk, Morgan Stanley for stock market indices. 
Latin America (seven largest economies): Changes in risk spreads and share prices

\begin{tabular}{|c|c|c|c|c|c|c|c|c|c|c|c|c|}
\hline & $\begin{array}{l}\text { Latin } \\
\text { America }\end{array}$ & Argentina & Brazil & Chile & Colombia & Mexico & Peru & $\begin{array}{l}\text { Vene- } \\
\text { zuela } \\
\text { (B. R.) }\end{array}$ & $\begin{array}{l}\text { Non-Latin } \\
\text { America } \\
\text { EMBI }\end{array}$ & $\begin{array}{c}3 \\
\text { months }\end{array}$ & $\begin{array}{c}\text { United } \\
\text { States } \\
\text { interest } \\
\text { rates } \\
1 \text { year }\end{array}$ & 10 years \\
\hline \multicolumn{13}{|c|}{ A. EMBI Global ${ }^{\mathrm{a}}$ (change in basis points) } \\
\hline Jul 04-abr 06 & -362 & -4680 & -375 & -2 & -278 & -66 & -219 & -417 & -147 & 323 & 277 & 57 \\
\hline Apr-jun 06 & 37 & 71 & 37 & 5 & 82 & 19 & -3 & 59 & 41 & 22 & 31 & 5 \\
\hline Jun-dec 06 & -51 & -169 & -62 & 1 & -78 & -39 & -84 & -43 & -39 & 2 & -21 & -41 \\
\hline Dec 06-jun 07 & 16 & 109 & -30 & -1 & -42 & -4 & -1 & 171 & 1 & -21 & -9 & 32 \\
\hline Jun-aug 07 & 53 & 125 & 35 & 24 & 78 & 20 & 49 & 125 & 53 & -77 & -72 & -49 \\
\hline Apr 06-aug 07 & 55 & 136 & -20 & 29 & 40 & -4 & -39 & 312 & 56 & -74 & -71 & -53 \\
\hline Jul 04-aug 07 & -307 & -4544 & -395 & 27 & -238 & -70 & -258 & -105 & -91 & 249 & 206 & 4 \\
\hline \multicolumn{13}{|c|}{ B. Share prices (percentage change in dollar terms) } \\
\hline Jul 00-jul 04 & 5.7 & -42.4 & -13.4 & 22.9 & 188.1 & 22.1 & 99.5 & 7.0 & & & & \\
\hline Jul 04-apr 06 & 140.9 & 222.3 & 176.1 & 63.8 & 277.5 & 113.2 & 82.3 & 21.0 & & & & \\
\hline Apr-jun 06 & -10.7 & -12.9 & -11.2 & -8.9 & -30.2 & -9.4 & -3.1 & -3.3 & & & & \\
\hline Jun-dec 06 & 26.5 & 24.7 & 21.1 & 27.6 & 39.1 & 36.5 & 23.5 & 15.9 & & & & \\
\hline Dec 06-jun 07 & 25.3 & 3.4 & 29.6 & 26.7 & 9.9 & 18.5 & 62.3 & 2.6 & & & & \\
\hline Jun-aug 07 & -5.8 & -4.5 & -4.9 & -6.1 & -6.7 & -8.2 & 1.2 & -1.8 & & & & \\
\hline Abr 06-aug 07 & 33.4 & 7.2 & 32.5 & 38.4 & -0.6 & 34.6 & 96.4 & 12.8 & & & & \\
\hline$<$ Jul 04-aug 07 & 221.5 & 245.6 & 265.9 & 126.7 & 275.4 & 187.0 & 257.9 & 36.5 & & & & \\
\hline
\end{tabular}

Source: JP Morgan Chase for spreads, Morgan Stanley for stock market indices, Federal Reserve data for United States interest rates.

a EMBI: Emerging Markets Bond Index.

and Peru, low initial spreads in Chile and Mexico mean that these countries have faced upward pressure on par short-term interest rates (table 3 ). ${ }^{4}$

The exuberance in the financial markets was transmitted to the Latin American economies through three different channels. First, the reduction of country risk spreads created direct pressure for lower domestic interest rates. A second and sometimes complementary development was that this pressure fed through to exchange rates. Growing foreign investment in localcurrency stock and bond markets thus began to create an ever-closer link between domestic and external markets, potentially affecting both interest and exchange rates;

\footnotetext{
${ }^{4}$ The cut-off date for table 3 is August 2007. It therefore excludes developments subsequent to the Federal Reserve interest rate cuts of mid-September, which triggered a new upsurge whose duration and intensity were not yet clear at the time this essay was completed.
}

furthermore, these effects could be multiplied by the derivatives markets. Third, the strong risk appetite characterizing this situation was reflected in investments in the domestic capital markets of the region's countries, which generated asset inflation in stock markets. As figure 4, panel B indicates, the beginning of the great Latin American stock market boom coincided with the start of the rapid fall in the region's risk spreads.

The two periods of turmoil in international financial markets in recent years also left a clear mark on this process. The first, in April and May 2006, originated in emerging markets (especially China), while that of late July and early August 2007 had its epicentre in the United States. The Latin American economies were affected by contagion in both cases. This is reflected above all in the high correlation between the average risk spread of emerging markets and the exchange rates of the region's seven largest economies in the two periods of upheaval, with the exception of Peru in both periods 
Latin America (seven largest economies):

Volatility of risk spreads and exchange rates during two periods of turbulence

\begin{tabular}{|c|c|c|c|c|c|c|c|c|}
\hline & Argentina & Brazil & Chile & Colombia & Mexico & Peru & $\begin{array}{l}\text { Venezuela } \\
\text { (B.R.) }\end{array}$ & EMBI+ ${ }^{\mathrm{a}}$ \\
\hline \multicolumn{9}{|l|}{ Spread volatility ${ }^{b}$} \\
\hline May-July 2006 & 26.2 & 19.6 & 3.6 & 27.7 & 14.7 & 10.1 & 20.9 & 16.4 \\
\hline July-September 2007 & 60.6 & 21.9 & 14.5 & 31.6 & 15.0 & 23.5 & 64.6 & 25.0 \\
\hline \multicolumn{9}{|l|}{ Exchange-rate volatility ${ }^{c}$} \\
\hline May-July 2006 & $0.56 \%$ & $3.24 \%$ & $2.11 \%$ & $3.12 \%$ & $1.81 \%$ & $0.57 \%$ & $2.24 \%$ & \\
\hline July-September 2007 & $0.78 \%$ & $2.95 \%$ & $0.91 \%$ & $4.51 \%$ & $1.21 \%$ & $0.57 \%$ & & \\
\hline \multicolumn{9}{|c|}{ Correlation between exchange rate and EMBI+ } \\
\hline May-July 2006 & 0.789 & 0.832 & 0.796 & 0.885 & 0.755 & -0.388 & 0.477 & \\
\hline July-September 2007 & 0.818 & 0.658 & 0.364 & 0.789 & 0.930 & 0.059 & & \\
\hline
\end{tabular}

Source: Estimated on the basis of information from JP Morgan Chase.

a EMBI+: index of high-risk emerging-market bonds.

b Standard deviation, expressed in basis points.

c Coefficient of variation (standard deviation expressed as $\%$ of the mean).

and, to some extent, of Chile in the most recent one; this correlation does not affect the Bolivarian Republic of Venezuela, which has had a fixed exchange rate since 2005 (table 4).

Among the region's largest countries, the one most affected in country risk terms during the first phase of upheaval was Colombia, followed by Argentina. However, exchange-rate volatility had the greatest effects in Brazil and Colombia. ${ }^{5}$ All stock exchanges saw price falls. The combined effect of lower share prices and a depreciating peso was very marked in Colombia, whose stock market fell by $30 \%$ if share prices are measured in dollars (table 3). With hindsight, we now know that the appetite for risk in international markets remained strong, turning this financial collapse into a mere ripple in the upward trend of stock markets (figure 4, section B). Risk spreads were back to normal by the end of the year and the downward trend in spreads became perceptible again in the first half of 2007, except in the cases of Argentina and the Bolivarian Republic of Venezuela. There began to be a perception that these two countries were affected by a type of risk that may perhaps be most appropriately

\footnotetext{
${ }^{5}$ In the case of Colombia, the exchange-rate volatility of recent times (the highest of any Latin American economy) stands in contrast to the first half of the present decade, when volatility was normal by international standards. See Banco de la República (2007).
}

defined, in the terminology of the markets, as "political" (Ecuador, which does not appear in the table, had experienced something similar in 2006).

The "flight to quality" which characterized the crisis of July-August 2007 had a larger impact on high-risk securities in the United States market than on emerging markets (figure 4, panel A). ${ }^{6}$ This time, in fact, the main mechanism of contagion was the liquidation of investors' positions in emerging markets to cover losses or liquidity needs in the markets of the United States and other industrialized countries. Among the largest Latin American nations, Argentina, Colombia and the Bolivarian Republic of Venezuela were most affected by rising risk spreads, and Brazil and Colombia once again by exchange-rate volatility. Chile and Mexico, along with Colombia, were the countries where the impact on stock markets was greatest (table 3). An interesting feature of a crisis that had its epicentre in the United States market is that the "flight to quality" has been reflected in rising prices for Treasury bonds, and interest rates for all terms have tended to fall as a result, with the shortest-term rates also being forced downward by the decision of the Federal Reserve to cut

\footnotetext{
${ }^{6}$ See ECLAC (2007b) for an analysis of the effects of this crisis on Latin America.
} 
the discount rate on 17 August and the federal funds rate on 18 September. Indeed, these cuts in reference rates were greater than the rise in the risk spreads of several Latin American countries, so that their par interest rates actually fell slightly during the crisis.

Although the debate about the implications of the recent financial market shock on economic growth in the United States and the world continues, the crisis had what may be a lasting effect on the behaviour of financial agents. Some developments in the United States over the last few months are very familiar to Latin American countries and the developing world from their own crises. Some examples are: the widening contagion of a problem that arose in one segment which everyone believed to suffer from problems specific to that segment rather than being more widely spread, the illiquidity of highrisk securities and debts, the lack of information about portfolio quality, and the "flight to quality" by all agents, including the main financial intermediaries. In any event, the market euphoria that followed the 18 September cut in the discount and federal funds rates was also reflected by the surge in Latin American stock markets, making the stock market turmoil of July and August look even more insignificant than that of the second quarter of 2006 (figure 4, panel B). The appreciating tendency of Latin American currencies had begun before 18 September and temporarily accelerated after that date.

One controversial issue has been the effect of fluctuations in international financial markets on the exchange rates of the Latin American countries. Machinea and Kacef (2007) prepared an analysis according to which changes in the real exchange rates of the Latin American countries (calculated as the ratio between real exchange rates in 2005 and the average for the 1990s) reflect the pressures from improvements in the terms of trade and the rise in remittances from Latin American workers abroad, rather than phenomena associated with the capital account. However, this analysis, valid if the 1990s are taken as the point of comparison, does not explain the dynamics of exchange rates during the recent boom or the strong upward pressure in real terms on the currencies of Brazil and Colombia, the two countries in Latin America where this tendency has been most striking in the last three years and where exchange-rate volatility has been greatest during periods of turmoil in the international financial markets.

As figure 5 shows, there is no systematic relationship between improving terms of trade and movements in real exchange rates since 2004, a period that coincides with the commodity price boom. The chart bears this out. Among the larger countries, the great improvement in the terms of trade may have been responsible for the real appreciation of the Chilean peso at an early stage, or of the Venezuelan bolívar more recently (although this currency does not show any real appreciation during the 2003-2006 period as a whole). But improved terms of trade certainly do not account for the large appreciation that the Brazilian and Colombian currencies have experienced in real terms.

As figure 6 confirms, the dynamics of exchange rates in these last two countries is unequivocally associated with fluctuations in private-sector financial flows. Both countries had experienced a large devaluation in the third quarter of 2002, coinciding with rising emerging-market risk spreads (figure 4, panel A). In the case of Brazil this was also associated with market speculation during that year's presidential elections. The exchange rate in Brazil strengthened and stabilized in the first half of 2003 while in Colombia it appreciated more gradually, but by mid-2004 neither of the two countries had returned to the levels of the first half of 2002 .

Strong currency appreciation in Brazil and Colombia over recent years has exactly coincided with the two phases of exuberance in international financial markets, the first of which can be situated, on the basis of the preceding analysis, between mid-2004 and April 2006, and the second between mid-2006 and mid-2007. Currency appreciation in both countries during these periods was clearly associated with capital flows, as is shown by the behaviour of net portfolio flows in the case of Brazil and net private-sector capital inflows in Colombia's foreign exchange balance (i.e., flows involving movements of liquid resources). In the case of Brazil, net portfolio flows had averaged US $\$ 44$ million a month in the four years prior to the first of these booms (i.e., between July 2000 and June 2004), rising to US\$ 309 million a month between July 2004 and April 2006. In the case of Colombia, net inflows in the private-sector foreign exchange balance averaged US\$232 million a month during this first phase of exuberance, having been slightly negative between July 2000 and June 2004. In both cases, the combination of larger inflows of short-term capital and lower risk spreads resulted in a large appreciation of the local currency. The central banks of both countries began intervening in the currency markets during this period but, as we shall see later, only to a modest extent.

The episode of April-May 2006 led to an outflow of capital from Colombia that had a considerable impact on net capital flows, exchange rates and, as we have seen, the stock market. The outflow of short-term capital was also large in Brazil, but the effects were smaller. Capital began to flow in again in the second half of 2006, and the flow became an avalanche in the first half of 2007 , 
Latin America (16 countries): Relationship between improved terms of trade and real currency appreciation, 2003-2006

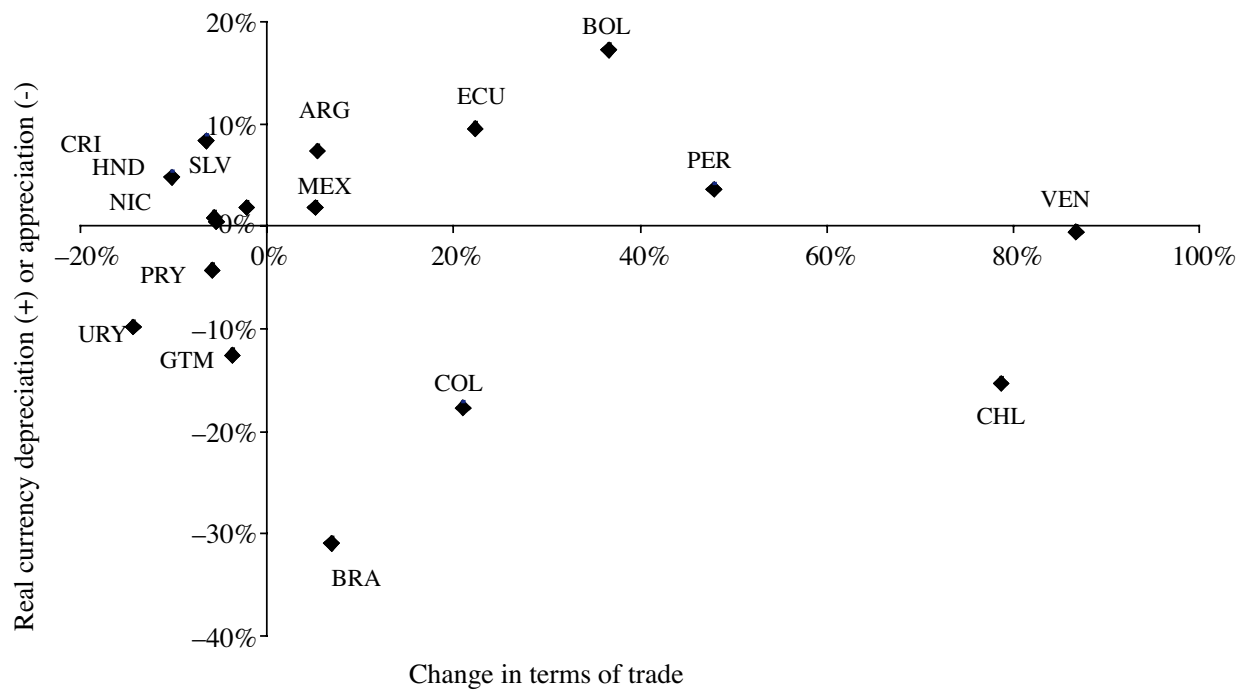

Source: Author's calculations based on data from ECLAC (2007).

when net private-sector capital inflows through the capital accounts reached US\$ 4,011 million a month in Brazil and US\$ 751 million in Colombia, i.e., multiples of the amounts entering in the first period of market exuberance. Indeed, as figure 6 shows, the size of the capital inflow has been so much greater than the amounts normally received by these countries that it can only be explained by speculation based on the belief that their central banks will have to let their currencies appreciate. Continuing high interest rates in Brazil and the clear expectation that overheating in the economy would force Colombia's Banco de la República to raise rates, as indeed it had been doing since the second half of 2006, explains why this seemed like a "sure bet" to speculators. This is on top of the relative fiscal weakness of the two countries and the fact that, as we have seen, both have experienced a large reduction in country risk spreads.

The central banks of Brazil and Colombia intervened massively during the second episode of financial market exuberance, increasing their international reserves by just over US $\$ 61$ billion and US\$ 6.1 billion, respectively, in the first half of 2007. This intervention did not prevent both countries' currencies from appreciating further, however. In May, Colombia also reintroduced a legal reserve requirement of $40 \%$ for incoming financial capital, a mechanism that had been successfully employed during the boom in capital flows of the 1990s. The introduction of the reserve requirement resulted in a fall in net capital inflows in June (i.e., before the United States financial crisis became apparent), indicating that it had some effect.

The recent shock in international financial markets led to a fresh reversal of these tendencies, and the effects were felt much more strongly once again in Colombia. Indeed, while the Colombian peso shed a great deal of the strength it had gained in the first half of 2007, the same did not happen with the Brazilian real. It was these two countries, furthermore, that saw their currencies appreciate most from mid-September onward as a result of the new market euphoria generated by the decisions of the Federal Reserve.

The rise in private capital flows during the two periods of exuberance in international financial markets was a more general phenomenon, however, as the capital accounts of the main Latin American countries indicate. Figure 7 compares aggregate current account balances with capital account balances for six of the region's seven largest economies (the Bolivarian Republic of Venezuela is excluded for the reasons set out in section II of this paper). Capital account balances, which were virtually nil between mid-2002 and mid-2004, recovered and began to outstrip those of the current account as a source of surpluses in the balance of payments. After the shock which hit the markets in the second quarter of 2006, capital inflows swelled enormously during the 
FIGURE 6

Brazil and Colombia: Exchange rates, portfolio flows and capital flows

A. Brazil: exchange rate and net portfolio flows

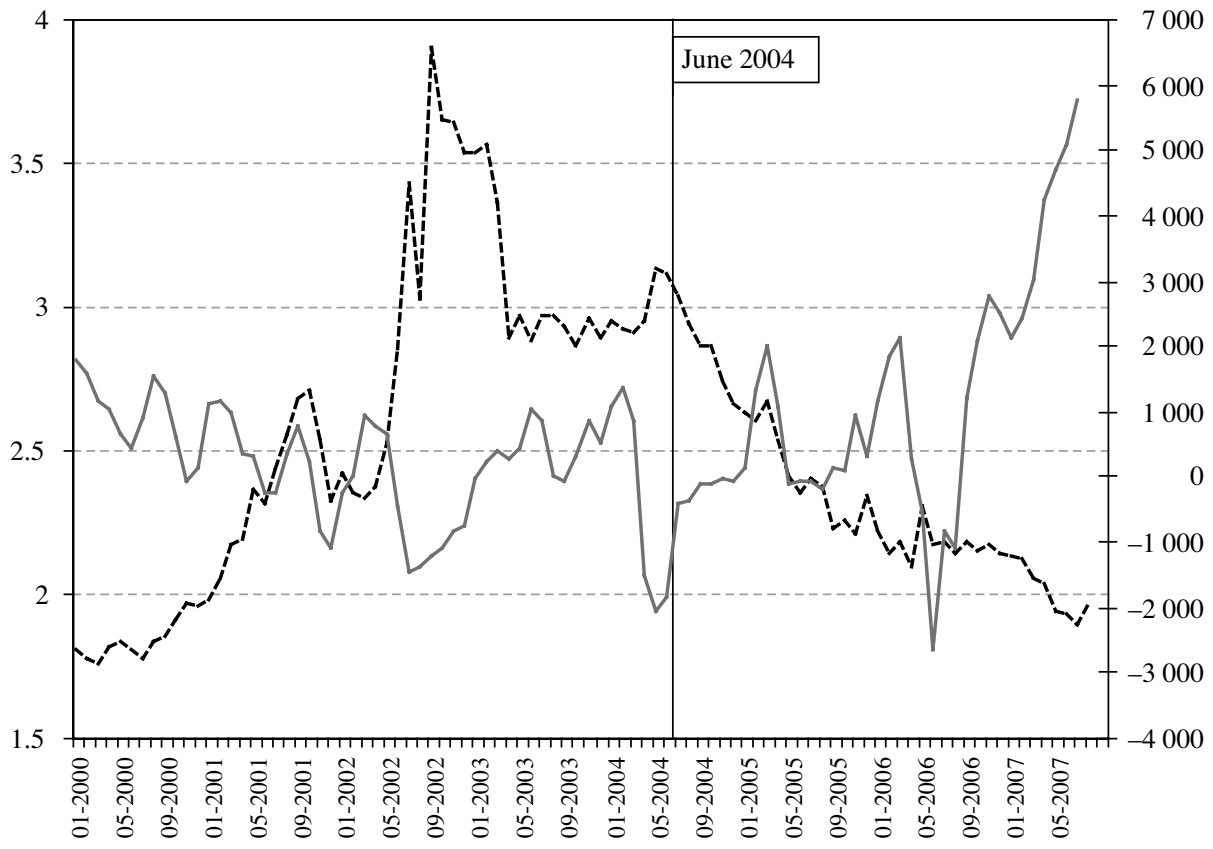

------ Exchange rate —— Portfolio flows (3-month average)

B. Colombia: exchange rate and private capital through foreign exchange balance

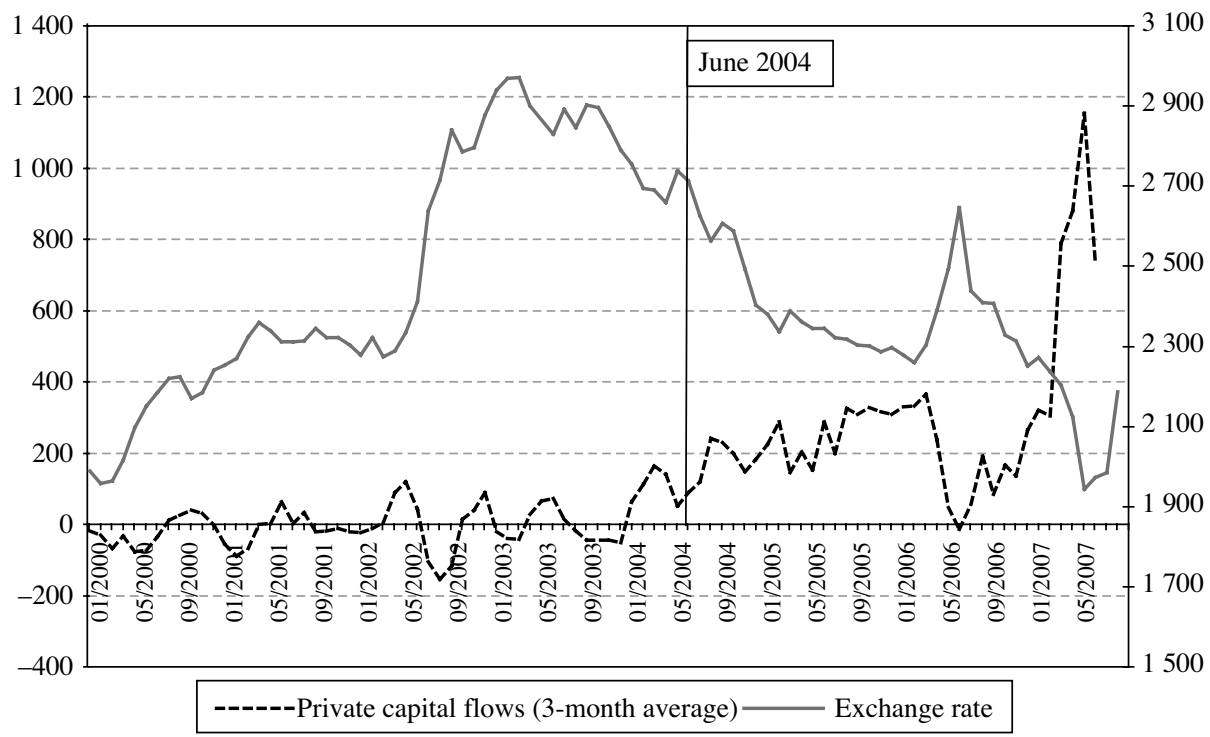

Source: Central Bank of Brazil and Banco de la República, de Colombia. 
second period of exuberance. The figures are telling: in the six countries considered, the balance-of-payments surplus during the last quarter of 2006 and the first half of 2007 was some US\$ 113 billion dollars, of which about US $\$ 100$ billion came from the capital account (roughly two thirds went to Brazil and the remainder to the other five economies). As we shall see in the following section, the currency authorities reacted correctly to this recent avalanche of capital, building up international reserves on a scale unprecedented in the region's history.
There can be no doubt, then, that while other phenomena have been influencing the currency markets, speculative capital flows have been a factor and indeed have played a crucial role in the two countries that seemed the surest bet to speculators. One consequence of this is that the large international reserves currently held by Latin America are offset by a large amount of potentially reversible capital, particularly in the cases of Brazil and Colombia. The high degree of correlation between exchange rates and risk spreads during the two market shocks that have followed the two phases of euphoria also bear out this interpretation.

FIGURE 7

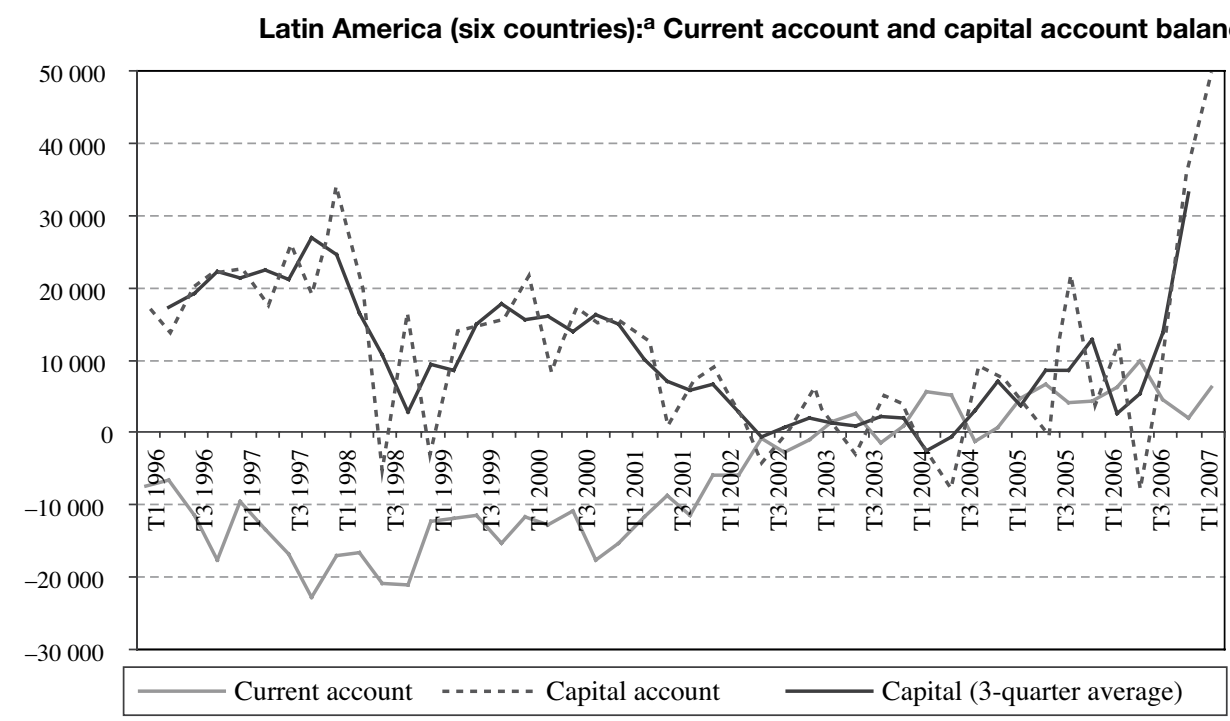

Source: Author's estimates based on data from IMF, International Financial Statistics, updated with information from the countries' central banks. In the case of Chile, funds accumulated in the stabilization funds are deemed equivalent to reserves.

a Argentina, Brazil, Chile, Colombia, Mexico and Peru.

\section{IV}

\section{Changes in macroeconomic policy}

The history of the last few decades in Latin America has been marked by procyclical macroeconomic policies that have boosted economic growth during periods of external buoyancy but built up vulnerabilities that make themselves felt when these exceptional external conditions come to an end.

The economic reforms of the last few years have affected the cyclical behaviour of the Latin American economies in three different ways. First, liberalization of the capital account has reduced the scope for independent management of monetary and exchange-rate policy; efforts to prevent appreciation during upturns result in a loss of freedom to adopt countercyclical monetary policies, while non-intervention in the currency market can mean a high degree of exchange-rate volatility. Second, the combination of capital market 
liberalization and domestic financial liberalization has reinforced the operation of the financial accelerator, which tends to increase lending, asset inflation and private expenditure during upturns only for the opposite to occur in downturns. Third, the increased incomeelasticity of short-term import demand has made the current account more sensitive to the business cycle: the conjunction of higher demand growth and real currency appreciation results in a rapid deterioration of the current account during upturns, but this is also corrected more quickly during crises. Of these three mechanisms, only the last could be considered to have some countercyclical effects, insofar as the domestic effects of the procyclical behaviour of private spending are thereby smoothed. But the price for this is that it also contributes to these economies' external vulnerability during upturns.

An interesting corollary of the cyclical behaviour of economies subject to procyclical inflows of external financing is that the "twin deficit" of current account variations is the private-sector balance, not the publicsector one. This can be clearly seen in figure 8: the large current account adjustment experienced by the Latin American economy between 1998 and 2003 resulted from an improvement in the private-sector balance; the deterioration in the current account over the last three years, when adjusted for the terms of trade, is the result of a deterioration in that same balance. This also seems to be a general characteristic of "successful" countries during upturns, as Marfán (2005) points out.

In this context, and in very open economies generally, it can be said that the only really autonomous policy instrument available to the economic authorities is fiscal policy. According to economic theory, this is also the most powerful instrument for affecting economic activity in economies whose capital markets have been liberalized. However, fiscal policy has also been subject to procyclical behaviour, for two different reasons. The first is the direct effect generated by the availability of resources, whether tax revenues or financing: the abundance of resources during upturns tends to increase public spending, while lower revenues, combined with the higher cost of debt servicing, lead to cuts in primary spending during crises. The second concerns political pressures on economic policymaking: after a period of public spending cutbacks, it is hard to convince the population of the virtues of a continuing programme of austerity. This is even truer if the justification for the austerity programme during the upturn is the need to offset the exuberance of private spending (Marfán, 2005).

Analysis of the most recent Latin American cycle confirms the procyclical behaviour of private and public expenditure and of the monetary and credit variables, with some interesting variants. In economies with net foreign-currency liabilities, the tendency towards currency appreciation during upturns generates positive wealth effects which help to boost private demand. ${ }^{7}$ As already noted, the most important countercyclical element is the large rise in imports resulting from high income-elasticity and real currency appreciation, which shift a large portion of demand abroad. Thus, the effects of real appreciation on the current account are countercyclical, unlike wealth effects. The behaviour of imports does, however, produce a rapid deterioration in the balance-of-payments current account, helping to create the conditions for the next downturn. The main "twin deficit" of the current account is the private deficit, as we have seen, but in the Latin American countries it has been common for public-sector deficits to increase at the same time.

Once the downturn has started, the most important development is the collapse of private spending, although the effects of this on aggregate demand are smoothed by the even faster decline in imports. During this phase, currency depreciation once again has a procyclical wealth effect (the loss of wealth associated with net liabilities denominated in foreign currencies) that contributes to the contraction of demand. It also sets up a countercyclical effect that operates through the balance-of-payments current account but takes time to make itself felt fully in the economy, partly because of the financial shocks that characterize the initial phase of the downturn. Monetary and credit policy also has procyclical effects to begin with, either because the authorities try to smooth the inflationary effects of depreciation by measures such as higher interest rates or credit restraint, or both, or simply because private-sector credit collapses while higher country risk spreads place pressure on domestic interest rates.

\footnotetext{
7 Note that when net financial balances turn positive, as they have now done in three of the region's seven largest economies, this wealth effect becomes countercyclical in relation to the economy as a whole. To ascertain whether the argument remains valid, however, it would be necessary to calculate the net financial balance of the private sector. In most cases, it is the public sector that has built up a positive net financial balance (this is even true of Brazil, whose net financial balance is still negative).
} 


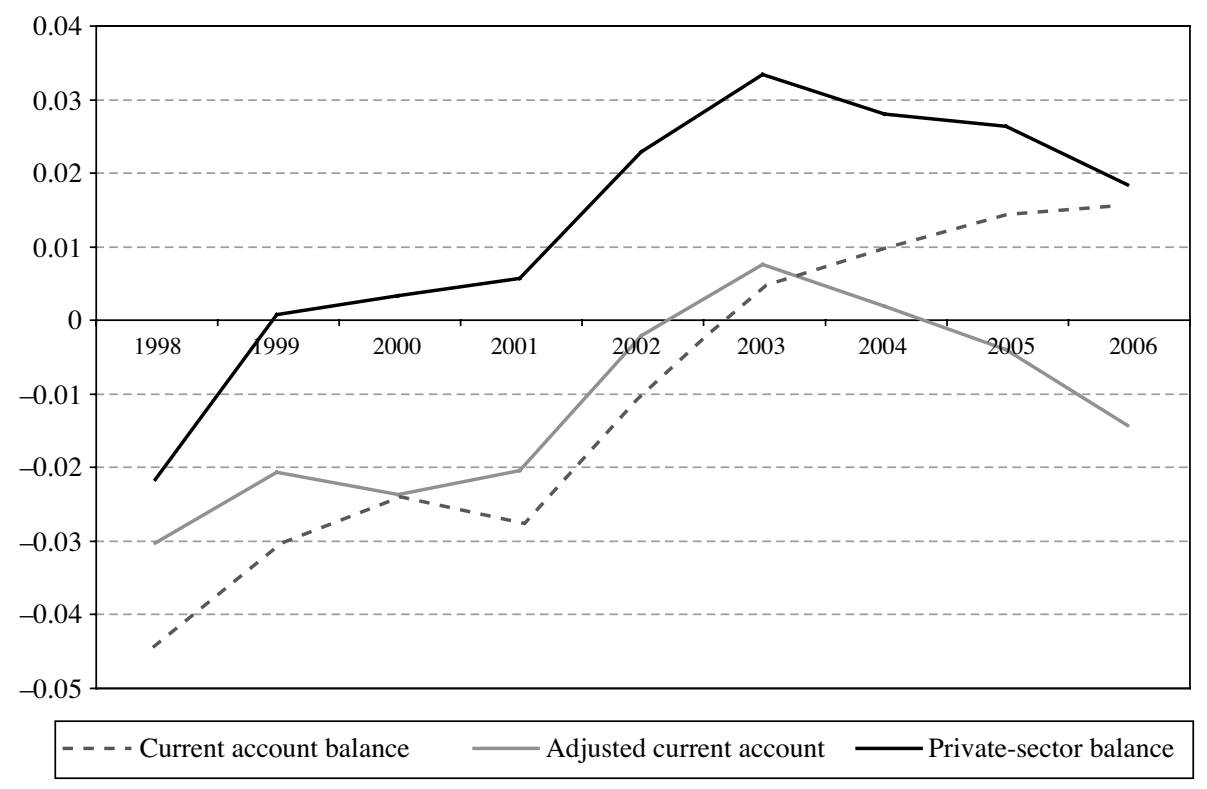

Source: Author's calculations based on data from ECLAC (2007).

The most important countercyclical factor operating initially in several Latin American economies has been public spending, which tends to hold up or even increase when a crisis breaks. As the fiscal accounts deteriorate, however, financing constraints are brought in, leading to measures to correct the deficit, either by increasing revenue or by reducing expenditure. Meanwhile, currency depreciation begins to have ever stronger countercyclical effects on the balance-of-payments current account, while the large depreciation that has built up in real terms allows the authorities concerned to loosen monetary policy. The countercyclical role played by these two factors is vital during the recovery phase and relieves fiscal policy of this task to some degree.

Generally speaking (although there are variations from one country to another), the Latin American countries were in the initial adjustment phase during the 1998-2001 period, passing to the second phase in 2002-2003. The first phase was characterized by a rapid correction of private-sector deficits and, in some cases, a deterioration in the fiscal accounts; in the second, on the other hand, the public accounts tended to do better while those of the private sector improved yet further. In practice, the private-sector deficit for the region as a whole (estimated rather crudely by deducting the central government balance from the current account balance) was corrected in 1999, even as the public-sector deficit continued to worsen (as shown by the gap between the two lines in figure 8); then in 2002 the budget deficit began to shrink (very slowly), while the private-sector surplus increased yet further.

In this context, what new developments have there been in Latin America during the recent upturn? As figure 8 shows, in the region as a whole the upturn has served to correct the budget deficit left over from the downturn. The private-sector accounts, on the other hand, have followed the pattern typical of previous upturns by starting to deteriorate, although they are still in surplus. Naturally, the calculations would alter if in each case we were to discount the gain of a little over three percentage points of GDP in the terms of trade; in the private sector, particularly, this would mean discounting the effect of the upturn on foreign firms operating in the hydrocarbon and mining sectors, where prices have risen most sharply.

The first great difference from the past seems to lie, then, in fiscal management. However, the story is rather less favourable than the aggregate figures suggest. Table 5 shows what has happened with primary spending by the central government in the seven largest Latin American countries. Strictly countercyclical fiscal management during upturns requires not only that extraordinary 
fiscal revenue be saved, but also that primary spending be reduced as a proportion of GDP, as this expenditure should follow the long-term trend of GDP growth. On this definition, only Chile and Peru have followed countercyclical fiscal policies, underpinned in Chile by the redesign of the country's stabilization funds (Economic and Social Stabilization Fund and Pension Reserve Fund, since 2006) and in Peru by legally binding limits on primary spending increases; in this latter case, the rules concerned, which were changed in 2006, imply that public-sector investment in Peru will not be subject to these constraints in future, so that the countercyclical effect will wear off. The other countries in table 5 have operated procyclical fiscal policies, most strikingly in the case of the Bolivarian Republic of Venezuela. In the cases of Brazil and Mexico, it could perhaps be argued that the continuing weakness of economic growth makes a more expansionary fiscal policy advisable, while higher spending in Brazil might be justified by the fact that the country is running a large primary surplus. The first of these arguments has some merit. The second is clearly wrong: fiscal policy is procyclical in this case even if the public accounts yield a primary surplus.

The generally procyclical fiscal policy that continued to be applied in some countries during the recent upturn is at odds, of course, with the complex institutional apparatus created in the late 1990s, when numerous fiscal responsibility laws were passed and stabilization funds established. Rule changes and the earmarking of resources indicate that these institutions have had only a limited impact so far (Jiménez and Tromben, 2006).

Again, the combined effect of the current upturn and higher prices for hydrocarbons and mining products has had as its corollary that countries with an export base of this type are generally the ones to have benefited most in terms of public revenue (Jiménez and Tromben, 2006). This is what has happened, most particularly, in Chile and the Bolivarian Republic of Venezuela (and Bolivia among the smaller countries $)^{8}$ and, to a lesser extent, in Colombia and Peru. The effect has been strengthened by a rising tax burden on these sectors, especially in Bolivia, Ecuador and the Bolivarian Republic of Venezuela in the case of hydrocarbons and Chile in the case of copper (special tax on the operating revenues of mining companies). In the case of Argentina, it must be recalled that the country strengthened its tax base

8 This is not the case with Ecuador, since the country is using much of its additional oil surplus to subsidize domestic fuel consumption. at the beginning of the upturn by appropriating some of the benefits accruing to certain commodities from real exchange rate depreciation by means of so-called "retentions" on exports; in 2007 it did much the same thing, only this time by appropriating part of the increase in international commodity prices.

The second major new development is the frequency and scale of official intervention in the currency markets, reflected in the build-up of external assets by central banks and, in the case of Chile, by the government in fiscal stabilization funds. This means that the leading Latin American economies (with the exception of the Bolivarian Republic of Venezuela since 2005) generally operate a "dirty" float (with variants, as will be seen later). Thus, the countries have usually opted for "intermediate" managed exchange-rate regimes, running counter to the orthodox recommendation of adopting one of the two extremes: either a free float or a fixed parity (1990s Argentine-style convertibility or dollarization). What this suggests is that there is an implicit exchange-rate target. The benefits of exchange-rate targets have been analysed theoretically ${ }^{9}$ and their use can be justified in the light of Latin American economic history. The only explicit policy of this type is the one adopted by Argentina, where the maintenance of a competitive exchange rate is one of the cornerstones of macroeconomic policy. Indeed, the Argentine experience shows that, in situations where external financing is abundant, it is possible to exercise control over the exchange rate and interest rates simultaneously even with a liberalized capital account, which runs completely counter to the famous open economy "trilemma" (Frenkel, 2007).

As is very well known, a policy of this type requires that the build-up of international reserves during upturns be matched by measures to sterilize their monetary impact. Sterilization of this type is easier when there is a fiscal surplus. Otherwise (and as an additional measure in any event) it will be necessary to sterilize via a mix of traditional open market operations, sales of central bank-issued bonds in the market, or higher reserve requirements.

For this reason, in the Argentine model the fiscal surplus is an essential complement to the policy of maintaining a highly competitive exchange rate; the possible erosion of this surplus, if public spending continues its recent rate of increase, is a threat to the macroeconomic policy model adopted by Argentina.

\footnotetext{
9 See Williamson (2000), for example.
} 
TABLE 5

Latin America (seven largest economies): Monetary, credit and fiscal policy indicators (Percentages)

\begin{tabular}{|c|c|c|c|c|c|c|c|}
\hline & Argentina & Brazil & Chile & Colombia & Mexico & Peru & $\begin{array}{c}\text { Venezuela } \\
\text { (B.R.) }\end{array}$ \\
\hline \multicolumn{8}{|c|}{ A. Change in central government fiscal accounts as \% of GDP, 2003-2006 } \\
\hline Current revenues $^{\mathrm{a}}$ & 1.2 & 2.4 & 5.2 & 2.2 & 0.6 & 2.5 & 6.7 \\
\hline Primary spending & 0.7 & 2.1 & -2.5 & 1.4 & 1.3 & -0.5 & 4.9 \\
\hline Primary balance & 0.6 & -0.2 & 7.7 & 1.0 & -0.7 & 3.0 & 1.8 \\
\hline \multicolumn{8}{|c|}{ B. Central government fiscal balance, 2006} \\
\hline Primary balance & 2.7 & 2.1 & 8.4 & -0.3 & 0.1 & 3.2 & 2.1 \\
\hline Total balance & 1.0 & -3.1 & 7.7 & -4.4 & -2.0 & 1.4 & 0.0 \\
\hline \multicolumn{8}{|c|}{ C. Change in nominal interest rate, 2003-2006 } \\
\hline Policy ${ }^{b}$ & & -4.8 & 4.0 & 2.5 & 0.8 & 2.5 & \\
\hline Interbank & 3.5 & -8.1 & 2.3 & -0.5 & 0.7 & 2.0 & -8.0 \\
\hline \multicolumn{8}{|l|}{ D. Real interest rate (deposits) } \\
\hline 2003 & -2.9 & 6.3 & -0.1 & 0.6 & -1.4 & 0.8 & -10.6 \\
\hline 2004 & -1.7 & 8.3 & 0.9 & 1.8 & -1.9 & -1.2 & -7.5 \\
\hline 2005 & -5.4 & 10.1 & 0.9 & 1.9 & -0.5 & 1.0 & -3.7 \\
\hline 2006 & -4.0 & 9.4 & 1.7 & 1.9 & -0.3 & 1.2 & -3.0 \\
\hline \multicolumn{8}{|c|}{ E. Change in balances as \% of GDP, 2003-2006 } \\
\hline Monetary base & -0.1 & 0.9 & 0.3 & 1.2 & 0.5 & 1.0 & 3.4 \\
\hline M1 & 1.9 & 1.1 & 0.6 & 1.7 & 0.9 & 1.8 & \\
\hline M3 & 2.6 & 10.0 & -7.8 & 5.0 & 5.8 & 1.1 & 8.7 \\
\hline Lending to the private sector & 2.3 & 7.3 & 1.6 & 10.7 & 3.7 & -3.0 & 3.9 \\
\hline
\end{tabular}

Source: ECLAC for fiscal statistics, IMF International Financial Statistics for interest rates and monetary and credit variables (except in the case of the Bolivarian Republic of Venezuela, where they were estimated from ECLAC figures), JP Morgan Chase for basic policy rates.

a Total revenues in the case of Brazil and Mexico.

b Between June 2004 and September 2007. The equivalent rate for the United States rose by $3.75 \%$.

Precisely the opposite situation is found in Brazil and Colombia, since these two countries still have the largest overall fiscal deficits; this factor has unquestionably made them more vulnerable to currency speculation. Mexico has opted for a cleaner float. The same could be said of Chile, which operates a clean float from the exchange-rate policy standpoint, but whose government intervenes massively in the currency markets through the stabilization funds.

Figure 9 shows the scale of official intervention in the currency markets of six countries during the two phases of market exuberance discussed earlier, from July 2004 to April 2006 and from July 2006 to June 2007. In both cases, intervention included the accumulation of reserves, the use of these reserves to pay off IMF debts and, in the case of Chile, the build-up of stabilization funds abroad. For the sake of comparability, interventions have been calculated as an annual equivalent (the second period did actually last a year) and as a proportion of GDP. It can be seen that intervention took place on a large scale. This was particularly true of Argentina in the first period, followed by Peru and Brazil. In the second period, intervention was massive in Argentina, Brazil and Chile and very high in Colombia and Peru. In all cases, it far exceeded the current account surplus (Colombia is the only country of the five to run a current account deficit), indicating that it also absorbed surpluses from private-sector capital flows. Of the region's seven largest countries, Mexico is the only one where official intervention in the currency market has been limited.

Monetary and credit policies are very difficult to compare. Although national situations vary, all the countries had slightly or markedly procyclical monetary and credit policies during the recent upturn. This is reflected in basic intervention rates, which have risen by less than United States Federal Reserve rates 
FIGURE 9

Latin America (six countries):

Official intervention in currency markets, two periods

(Percentages of gross domestic product)

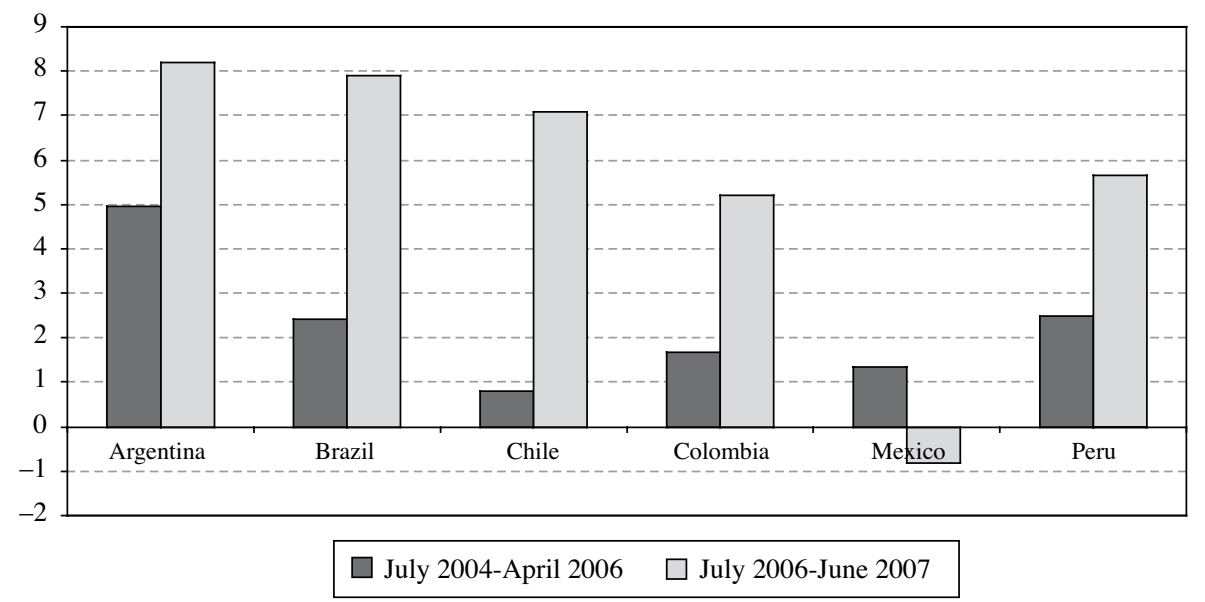

Source: Estimates based on changes in reserves as given by IMF International Financial Statistics. In the case of Chile, the later period includes resources saved in the Economic and Social Stabilization Fund and Pension Reserve Fund. Nominal dollar GDP is the average for 2004 and 2005 in the first period and the 2006 figure in the second. Reserves accumulated in the first period are calculated as a 12-month average equivalent.

(except in Chile, where it is slightly higher), and can be seen even more clearly in interbank rates (table 5). With the striking exception of Brazil (where real interest rates are still extremely high despite a large reduction in nominal rates), deposit rates have remained at very low levels in real terms (they were negative in three of the seven countries in 2006). In addition, with few exceptions, monetary and credit aggregates have risen as a proportion of GDP. The table shows two worrying cases of very rapid growth in financial system lending to the private sector: these are Brazil and Colombia, and it is no coincidence that they are the two countries where capital inflows have increased most dramatically. The Bolivarian Republic of Venezuela also displays clearly expansionary monetary and credit indicators.

One favourable trend on the monetary and credit front has been the "de-dollarization" of different countries in recent years. The most widespread development has been the tendency for foreign currency-denominated public-sector liabilities issued in local capital markets to dwindle or disappear. Argentina conducted a radical de-dollarization of its financial system during the crisis of the early part of the decade, and Peru has adopted a policy of gradual de-dollarization (together with Bolivia and Uruguay, among smaller countries).
Taking everything together, one of the most interesting conclusions from the analysis is that the macroeconomic policy challenges facing the region's main economies are highly diverse (although we are concentrating on the macroeconomic challenges, we are obviously aware that there are other major economic challenges, not least the need to diversify the production structure and, in certain countries, energy problems). Chile is in the soundest position, thanks to a successful countercyclical fiscal policy; this might be said to have gone too far in 2006, with the result that growth was relatively slow, but the situation has now been remedied. Peru is the country that most resembles Chile where fiscal policy is concerned. Argentina has also had a very successfully macroeconomic policy, grounded in a competitive currency and a fiscal surplus; if the recent upward trend in public spending is maintained, however, the second of these pillars will be eroded. Along with the Bolivarian Republic of Venezuela, furthermore, Argentina is the country with the highest inflation rate.

Exchange-rate competitiveness and the rapid growth of domestic credit are the main problems facing Brazil and Colombia, and their most obvious result is the deterioration of the current account, which is well advanced in Colombia and could materialize soon in Brazil. The combination of a more austere fiscal policy, monetary 
and prudential measures to check credit growth and greater intervention in the currency markets (including the reserve requirement for external financing adopted by Colombia in May 2007) may be the right answer. As long as these measures are applied, Brazil's high interest rates will continue to be a magnet for outside capital. Mexico, meanwhile, can be seen as an intermediate case in all the aspects analysed; its main problems concern competitiveness. This being so, it would not be illogical for this country to join the South American (and Asian)

\section{$\mathrm{V}$}

\section{Conclusions}

The analysis carried out here points to three conclusions. The first is that the region has already reaped considerable benefits by using the current commodity price boom as an opportunity to reduce external liabilities and build up international reserves. The build-up of reserves looks less impressive, however, when set against the concomitant increase in portfolio liabilities, whose essential characteristic during the recent upturn has been the increased quantity of resources invested by international investment funds in local stock and bond markets. At the same time, the current account, adjusted for the terms of trade, is deteriorating, and this will ultimately remove the most striking feature of the recent situation: the conjunction of a current account surplus with rapid economic growth. This combination, then, has its origin in an exceptional surge in hydrocarbon and mining product prices (more than agricultural prices) and does not reflect, as in East Asia, a high degree of international competitiveness.

The second conclusion is that we should remain aware of the potential of the international financial markets to deliver shocks like those occurring in a variety of forms over the past few years. The largest one was the massive influx of capital into the region's larger countries during the two periods of exuberance in international financial markets (between mid-2004 and April 2006, and between mid-2006 and mid-2007), particularly the second. In the two countries most sensitive to this phenomenon, Brazil and Colombia, the massive inflow of capital was reflected in the rapid growth of financial system lending to the private sector and excessive appreciation of the local currencies, the risks of which are now beginning to become clear. Insofar as the source of the disruption is the exuberance of financial trend towards more active exchange-rate management as part of its economic policy.

The Bolivarian Republic of Venezuela, lastly, has the most expansionary fiscal policy, while monetary and credit policy is also procyclical. Of the region's largest countries, therefore, it is the only one still engaging in patterns of macroeconomic behaviour that were widespread in Latin America in the past and that will be sustainable only if conditions in the oil market remain exceptional. markets, it is worth adopting preventive measures to check the inflow of capital. Chile and Colombia used these successfully in the 1990s. Colombia also adopted measures of this type during the recent boom, although only once the influx of capital and the appreciation of the currency had reached a very advanced stage.

Lastly, the two major (and complementary) macroeconomic policy developments that have occurred in Latin America in recent years need to be consolidated and applied more widely: countercyclical fiscal management, pioneered by Chile and to a lesser extent by Peru, and active currency market intervention, with the build-up of international reserves that this entails. The leading example of this latter policy is Argentina, where events have also underscored the complementary relationship between exchange-rate competitiveness and the maintenance of a fiscal surplus (although this risks being eroded because of the expansionary fiscal policy followed recently).

Where there is active intervention in currency markets, it may be worth acknowledging that the real exchange rate is a legitimate goal of macroeconomic policy, something that tends to be implicit rather than explicit in all countries but Argentina. The absence of an effective curb on currency appreciation can become a magnet for capital inflows in periods when privatesector agents are expecting this to occur. Brazil and Colombia have been obvious victims of the influx of speculative capital seeking to take advantage of these exchange-rate trends. There is an obvious risk in all the countries, but especially these two, that the flows may be reversed.

For this reason, it would not be illogical to move towards an asymmetrical currency regime designed to 
compensate for the asymmetry affecting developing countries in the international capital markets, i.e., easy access in upturns and inadequate access in downturns. This regime would establish an exchange-rate ceiling (which could take the form of a crawling peg during upturns), but would allow currencies to float during downturns. The international reserves accumulated during upturns would be used to intervene in currency markets during downturns to achieve an orderly exchange-rate adjustment and such other goals as the authorities may set themselves, particularly in relation to interest rates. The reserves build-up during upturns obviously needs to be properly sterilized, something that is easier to do if there is a fiscal surplus, i.e., a countercyclical fiscal policy.

(Original Spanish)

Bibliography

Banco de la República (2007): Volatilidad de la tasa de cambio, Documento SGMR-SGEE-017-01-J, Bogotá, D.C., January.

Calvo, G. and E. Talvi (2007): Current Account Surplus in Latin America: Recipe Against Capital Market Crises? Available at http://www.rgemonitor.com/latamblog/author/44//guillermo_ calvo_and_ernesto_talvi.

ECLAC (Economic Commission for Latin America and the Caribbean) (2006): Economic Survey of Latin America and the Caribbean, 2005-2006, LC/G.2314-P, Santiago, Chile. United Nations publication, Sales No. E.06.II.G.2.

(2007a): Economic Survey of Latin America and the Caribbean, 2006-2007, Briefing Paper, Santiago, Chile. (2007b): Confusion and uncertainty in credit markets, LC/WAS/R.47, Washington, D.C., ECLAC office in Washington, D.C., September.

Frenkel, R. (2007): La sostenibilidad de la política de esterilización, documento de trabajo, $N^{\circ}$.7, Buenos Aires, Centro de Economía y Finanzas para el Desarrollo de Argentina, August.

Izquierdo, A., R. Romero and E. Talvi (2007): Business Cycles in Latin America: The Role of External Factors, Washington, D.C., Inter-American Development Bank/CERES, September.

Jiménez, J.P. and V. Tromben (2006): Fiscal policy and the commodities boom: the impact of higher prices for non-renewables in Latin America and the Caribbean, CEPAL Review, No. 90, LC/G.2323$\mathrm{P}$, Santiago, Chile, December.

Kuczynski, P.-P. and J. Williamson (eds.) (2003): After the Washington Consensus: Restarting Growth and Reform in Latin America, Washington, D.C., Institute for International Economics.
Machinea, J.L. and O. Kacef (2007): La coyuntura económica de América Latina: ¿hay lugar para el optimismo?, in J.L. Machinea and N. Serra (eds.), Hacia un nuevo pacto social. Políticas económicas para un desarrollo integral en América Latina, Santiago, Chile, Economic Commission for Latin America and the Caribbean (ECLAC)/Fundación CIDOB.

Marfán, M. (2005): La eficacia de la política fiscal y los déficit privados: un enfoque macroeconómico, in J.A. Ocampo (ed.), Más allá de las reformas: dinámica estructural y vulnerabilidad macroeconómica, Bogotá, D.C., Alfaomega/ECLAC.

Ocampo, J.A. (2004): Reconstruir el futuro: globalización, desarrollo y democracia en América Latina, Bogotá, D.C., Grupo Editorial Norma/ECLAC.

Ocampo, J.A. and M.A. Parra (2003): The terms of trade for commodities in the twentieth century, CEPAL Review, No. 79, LC/G.2200-P, Santiago, Chile, April.

United Nations (2006): World Economic and Social Survey 2006: Diverging Growth and Development, New York. United Nations publication, Sales No. 06.II.C.1. (2007): World Economic Situation and Prospects 2007, New York. United Nations publication, Sales No. 07.II.C.2.

Williamson, J. (2000): Exchange rate regimes for emerging markets: reviving the intermediate option, Policy Analyses in International Economics 60, Washington, D.C., Institute for International Economics. 